\title{
Bronchial provocation tests in clinical practice
}

\author{
Teste de broncoprovocação na prática clínica
}

\author{
Marcos de Carvalho Borges', Erica Ferraz", Elcio Oliveira Viannal'I \\ Department of Medicine, Faculdade de Medicina de Ribeirão Preto (FMRP), Ribeirão Preto, São Paulo, and Universidade de São Carlos \\ (UFSCar), São Carlos, São Paulo, Brazil
}

\begin{abstract}
'MD, PhD. Visiting Professor, Department of Medicine, Faculdade de Medicina de Ribeirão Preto (FMRP), Ribeirão Preto, São Paulo, and Adjunct Professor, Department of Medicine, Universidade de São Carlos (UFSCar), São Carlos, São Paulo, Brazil.

"PhD. Research Collaborator, Department of Medicine, Faculdade de Medicina de Ribeirão Preto (FMRP), Ribeirão Preto, São Paulo, Brazil. "'MD, PhD. Associate Professor, Department of Medicine, Faculdade de Medicina de Ribeirão Preto (FMRP), Ribeirão Preto, São Paulo, Brazil.
\end{abstract}

\section{KEY WORDS:}

Bronchial provocation test.

Asthma.

Bronchoconstriction.

Diagnosis.

Respiratory hypersensitivity.

\section{PALAVRAS-CHAVE:}

Testes de provocação brônquica.

Asma.

Broncoconstrição.

Diagnóstico.

Hipersensibilidade respiratória.

\begin{abstract}
Bronchial hyperresponsiveness, which consists of an exaggerated response of the airways to bronchoconstrictor stimuli, is one of the main characteristics of asthma, presented in nearly all asthmatic patients. Bronchial hyperresponsiveness may also be present in other diseases, such as allergic rhinitis, chronic obstructive pulmonary disease, cystic fibrosis, heart failure and respiratory infection, and with some medications, such as $\beta$-blockers. Bronchial provocation tests (also known as bronchial challenges) are used to evaluate bronchial responsiveness. These tests have become increasingly used over the last 20 years, with the development and validation of accurate, safe and reproducible tests, and with the publication of welldetailed protocols. Several stimuli can be used in a bronchial challenge, and they are classified as direct and indirect stimuli. There are many indications for a bronchial challenge. In this review, we discuss the main differences between direct and indirect stimuli, and the use of bronchial challenges in clinical practice, especially for confirming diagnoses of asthma, exercise-induced bronchoconstriction and coughvariant asthma, and for use among elite-level athletes.
\end{abstract}

\section{RESUMO}

Hiperresponsividade brônquica, caracterizada por uma resposta exagerada das vias aéreas a um estímulo broncoconstritor, é uma das principais características da asma, presente em praticamente todos pacientes asmáticos. A hiperresponsividade brônquica pode estar presente também em outras doenças, como rinite alérgica, doença pulmonar obstrutiva crônica, fibrose cística, insuficiência cardíaca, infecção respiratória e com o uso de algumas medicações, como $\beta$-bloqueadores. Os testes de broncoprovocação são utilizados para determinação da responsividade brônquica, e têm sido cada vez mais utilizados nos últimos 20 anos com o desenvolvimento e validação de testes acurados, seguros e reprodutíveis e com a publicação de protocolos bem detalhados. Diversos estímulos podem ser utilizados em um teste de broncoprovocação, sendo classificados em estímulos diretos e indiretos. Existem inúmeras indicações para um teste de broncoprovocação. Nesta revisão, nós discutimos as principais diferenças dos estímulos diretos e indiretos e o uso desses testes na prática clínica, especialmente para a confirmação de asma, broncoconstrição induzida por exercício, tosse variante de asma e em atletas de elite.

\section{INTRODUCTION}

Bronchial responsiveness is characterized by a change in airway caliber in response to bronchoconstrictor and/or bronchodilator stimuli. Bronchial hyperresponsiveness (BHR) is defined as increased responsiveness in comparison with an expected response. This increased response of the airways can be measured by inhalation of specific or non-specific stimuli, and it should not be expected to be observed in normal subjects.

Bronchial hyperresponsiveness is measured in laboratories by a bronchial provocation test (also known as a bronchial challenge), and is considered present when the dose-response curve for a bronchoconstrictor stimulus displays: a leftward shift (hypersensitivity), an increased slope (hyperreactivity) and an enhanced maximal response compared with the response for a nonasthmatic subject..$^{1-3}$ In other words, BHR is detected by an abnormal response to a bronchoconstrictor stimulus.

Bronchial hyperresponsiveness is one of the main pathophysiological characteristics of asthma and is present in nearly all asthmatic patients, especially during symptomatic episodes. ${ }^{4}$ It can also be found in other diseases, such as allergic rhinitis, chronic obstructive pulmonary disease, cystic fibrosis and heart failure, or after a respiratory infection, and with some medications like $\beta$-blockers. ${ }^{3,4}$ Hyperresponsiveness can explain many clinical features of diseases, such as coughing, wheezing, chest tightness or dyspnea, which can occur after allergen 
or occupational exposure, physical activity, respiratory infections or medications. ${ }^{3,4}$

Although bronchial hyperresponsiveness is incompletely understood, it is the ultimate result from an interaction between complex and multiple mechanisms, such as inflammation, alterations in airway smooth muscle, airway remodeling, reduced airway caliber and interaction between airway and lung parenchyma. ${ }^{5-8}$ In this review, we discuss the main differences between direct and indirect stimuli, and the use of bronchial challenges in clinical practice, especially for confirming the diagnoses of asthma, exercise induced bronchoconstriction and

Table 1. Reviews and practice guidelines were searched in the Cochrane Library, PubMed, Scopus, Embase, Lilacs and Medline databases, using the keywords Bronchial Provocation Tests and Bronchial Challenge. Additionally, relevant original articles were included

\begin{tabular}{|c|c|c|c|}
\hline \multirow{2}{*}{ Database } & \multirow{2}{*}{ Search strategy } & \multicolumn{2}{|c|}{ Results } \\
\hline & & Found & Used \\
\hline Cochrane & Bronchial Provocation Tests (MeSH) & 0 & 0 \\
\hline Library & Bronchial Challenge (MeSH) & 2 & 0 \\
\hline \multirow{2}{*}{ PubMed } & Bronchial Provocation Tests (MeSH) & 585 & 13 \\
\hline & Bronchial Challenge (MeSH) & 49 & 2 \\
\hline \multirow{2}{*}{ Scopus } & Bronchial Provocation Tests (MeSH) & 607 & 14 \\
\hline & Bronchial Challenge (MeSH) & 386 & 13 \\
\hline \multirow{2}{*}{ Embase } & Bronchial Provocation Tests (MeSH) & 329 & 3 \\
\hline & Bronchial Challenge (MeSH) & 64 & 4 \\
\hline \multirow{2}{*}{ Lilacs } & Bronchial Provocation Tests (MeSH) & 1 & 0 \\
\hline & Bronchial Challenge (MeSH) & 1 & 0 \\
\hline \multirow{2}{*}{ Medline } & Bronchial Provocation Tests (MeSH) & 88 & 1 \\
\hline & Bronchial Challenge (MeSH) & 98 & 1 \\
\hline \multirow{3}{*}{$\begin{array}{l}\text { Description of } \\
\text { articles used in } \\
\text { our review }\end{array}$} & Review & & 20 \\
\hline & Practice guidelines & & 4 \\
\hline & Original studies & & 25 \\
\hline
\end{tabular}

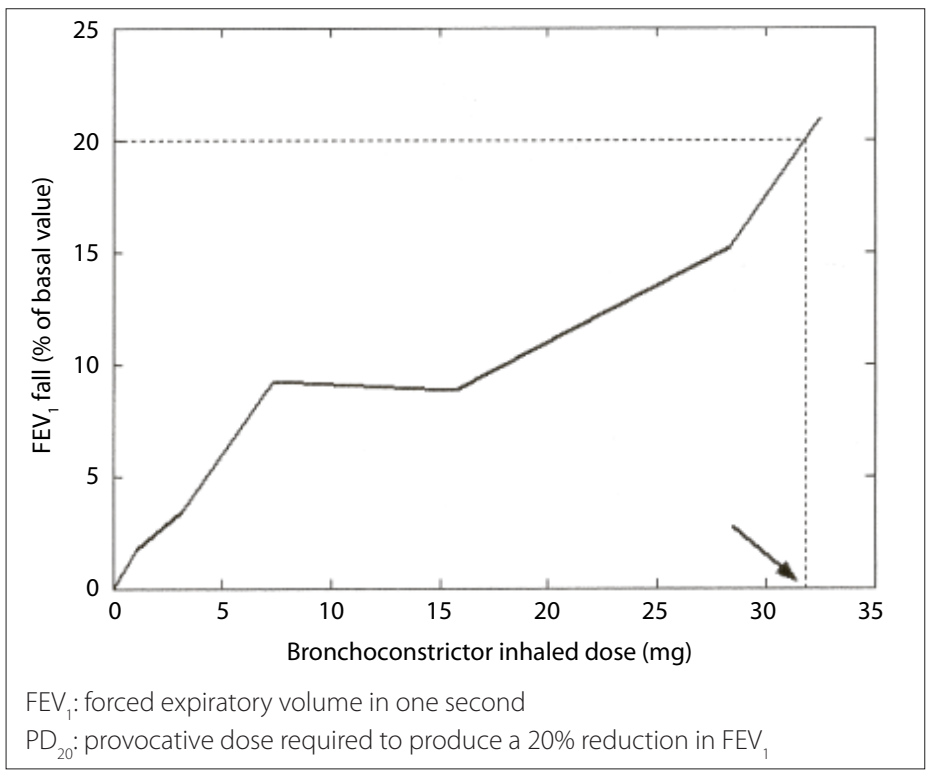

Figure 1. Example of $\mathrm{PD}_{20}$ calculation for hypertonic saline bronchial challenge obtained by interpolation between the last two points (second-to-last and final concentration) of the dose-response curve. cough-variant asthma, and for evaluating dyspnea among elitelevel athletes. Systematic reviews and practice guidelines were searched in the Cochrane Library, PubMed, Scopus, Embase, Lilacs, and Medline using the keywords Bronchial Provocation Tests and Bronchial Challenge. Additionally, we included some relevant original studies (Table $\mathbf{1}$ ).

\section{Bronchial provocation tests}

Generally, bronchial responsiveness is measured in the laboratory as the change in airway caliber occurring after inhalation of a bronchoconstrictor stimulus. ${ }^{2}$ These tests have become increasingly used over the last 20 years, with the development of accurate, safe and reproducible bronchial challenges, and with the publication of well-detailed protocols. Bronchial challenge tests are easily performed in adults and children more than seven years of age. ${ }^{3,6,9}$

Bronchial challenges are performed by the inhalation of a bronchoconstrictor stimulus followed by assessment of its response in terms of lung function, especially forced expiratory volume in one second $\left(\mathrm{FEV}_{1}\right)$. When a fall in $\mathrm{FEV}_{1}$ is achieved, usually between 10 and 20\% from the baseline measurement, the test is stopped and a concentration or dose is calculated and named provocative concentration (PC) or provocative dose (PD), respectively (Figure 1). ${ }^{3,6,9,10}$

The absolute contraindications for bronchial challenges are severe airflow limitation $\left(\mathrm{FEV}_{1}<50 \%\right.$ predicted or $\left.<1.0 \mathrm{l}\right)$, heart attack or stroke within the last three months, uncontrolled hypertension, systolic $\mathrm{BP}>200 \mathrm{mmHg}$, or diastolic $\mathrm{BP}>100 \mathrm{mmHg}$, and known aortic aneurysm. The relative contraindications are moderate airflow limitation $\left(\mathrm{FEV}_{1}<60 \%\right.$ predicted or $\left.<1.5 \mathrm{l}\right)$, inability to perform acceptable-quality spirometry, pregnancy, nursing mothers, current use of cholinesterase inhibitor medication (for myasthenia gravis) and epilepsy requiring medical treatment. ${ }^{3,69,10}$

Medications known to influence bronchial responsiveness should be withheld before the test: oral inhaled short-acting (e.g. salbutamol, terbutaline or fenoterol), medium-acting (e.g. ipratropium or theophylline) and long-acting (e.g. formoterol, tiotropium or salmeterol) bronchodilators should be withheld for 8, 24, and 48 hours, respectively; leukotriene modifiers for 24 hours; cromolyn sodium for 8 hours; nedocromil for 48 hours; and, except for methacholine challenge, antihistamines are withheld for their duration of action. Coffee, tea, cola drinks and chocolate should not be consumed on the day of the test. The intervals between exposures and tests should be taken into account. In order to avoid effects on the results, intervals should be respected, as follows: one to three weeks after environmental antigens, three to six weeks after respiratory infections, months after occupational sensitizers, one week after air pollutants and days to months after chemical irritants. ${ }^{3,6,9,10}$ 
Bronchial challenges should be performed in the presence of staff with appropriate training for treating acute bronchoconstriction, including appropriate use of resuscitation equipment, which must be close enough to respond quickly to an emergency. Medications to treat severe bronchoconstriction must be present in the room where the test takes place. They include epinephrine and atropine for subcutaneous injection, and salbutamol/ albuterol and ipratropium in metered-dose inhalers or premixed solutions for inhalation. Oxygen must be readily available. A small-volume nebulizer should be readily available for administration of bronchodilators. A stethoscope, sphygmomanometer and pulse oximeter should be available. Patients should not be left unattended during the procedure. Usually, the bronchoconstriction is transitory and easily managed with bronchodilators. The room needs to be efficiently ventilated, and staff with active asthma should not perform the test or be present in the room where it takes place. ${ }^{3,6,9,10}$

\section{Direct and indirect stimuli}

Several stimuli are in use for bronchial challenges, and each may constitute a piece of the jigsaw puzzle on the pathophysiology of BHR and respiratory diseases. ${ }^{11}$ The bronchial stimuli can be classified into direct and indirect stimuli, according to the main/dominant mechanism through which they cause the bronchoconstriction. ${ }^{12}$ This classification highlights the heterogeneity of the airway response to the different stimuli, and helps in understanding the differences in sensitivity and specificity of the stimuli and the effect of treatment on hyperresponsiveness. ${ }^{5,10,12}$ Therefore, the results from different bronchial challenges should be interpreted according to the stimulus used and the disease phase and treatment.

Direct stimuli cause bronchoconstriction acting on the effector cells, such as airway smooth muscle cells, bronchial vascular endothelial cells and mucus-producing cells. ${ }^{5}$ The main direct stimulus used in clinical practice is methacholine. Indirect stimuli cause bronchoconstriction through action on another cells, such as inflammatory cells, epithelial cells and/or neuronal cells, which interact secondarily with these effector cells. ${ }^{5,11}$ The main indirect stimuli used in clinical practice are hypertonic saline, mannitol, bradykinin, exercise and eucapnic voluntary hyperpnea. Some stimuli are able to cause bronchoconstriction through both direct and indirect action. Several stimuli used for bronchial challenge are listed in Chart 1.

Both direct and indirect stimuli can be used as complementary information in diagnosing respiratory diseases, such as asthma, cough and exercise-induced bronchoconstriction (EIB). Although there are differences in the airway response to the different stimuli, our experience shows that it is more important, in general practice, to get used to one bronchoconstrictor stimulus and protocol (thus knowing its advantages and limitations), than to use several stimuli only few times each (thus knowing several stimuli superficially).
The major difference between direct and indirect stimuli, in general practice, is the sensitivity and specificity of each stimulus in diagnosing respiratory diseases, especially asthma. Bronchial challenge with direct stimuli, such as histamine and methacholine, is extremely sensitive for diagnosing asthma patients. However, these stimuli lack specificity, both in differentiating asthma from normal and asthma from chronic airflow limitation. ${ }^{4}$ Therefore, while a positive challenge in a symptomatic patient, especially with direct stimuli, does not confirm asthma, a negative test has a highly negative predictive value and rules out asthma.

Indirect stimuli are used in bronchial challenges because of their higher specificity for identifying people with active asthma, and to evaluate treatments with anti-inflammatory drugs. ${ }^{5,10,12}$ The major advantage of indirect stimuli is their capacity to act on many different cells, so that a wide variety of substances contribute towards the airway narrowing (e.g., histamine, leukotrienes, prostaglandins and neuropeptides), which makes the response more similar to bronchoconstriction developed during daily activities. ${ }^{10,13,14}$ Since indirect stimuli have higher specificity, another advantage is the lack of false-positive tests; hence the interest in these stimuli in epidemiological studies on asthma prevalence. ${ }^{10,15}$ It has been suggested that indirect stimuli would better reflect the degree of airway inflammation than would direct stimuli, with greater usefulness for evaluating and monitoring the response to anti-inflammatory drugs. ${ }^{5,16,17}$

\section{The use of bronchial provocation tests in general practice}

There are many indications for a bronchial challenge, such as to confirm the diagnosis of asthma and/or EIB; to investigate cough-

Chart 1. Direct and indirect stimuli used to measure bronchial responsiveness. Direct stimuli cause bronchoconstriction through action on effector cells and indirect stimuli cause bronchoconstriction through action on another cells, which interact secondarily with the effector cells. Some stimuli are able to cause bronchoconstriction through both direct and indirect action. The stimuli are classified according their main/dominant mechanism

\begin{tabular}{|l|}
\hline Direct stimuli \\
Methacholine \\
Histamine \\
Acetylcholine \\
Carbachol \\
\hline Prostaglandin D2 \\
Leukotriene C4/D4/E4 \\
Indirect stimuli \\
\hline Hypertonic aerosols (hypertonic saline, mannitol) \\
Hypotonic aerosols \\
Exercise \\
\hline Eucapnic voluntary hyperpnea \\
Bradykinin \\
Adenosine \\
\hline Propranolol \\
\hline Metabisulphite \\
\hline Tachykinins
\end{tabular}


variant asthma; to investigate occupational asthma; to identify and evaluate the response and efficacy of drugs, like anti-inflammatory drugs; to collect sputum; to identify those who may experience airway narrowing while diving with self-contained underwater breathing apparatus (SCUBA); to clear unwanted secretions; to differentiate asthma from chronic airflow limitation; and to evaluate elite-level athletes. ${ }^{4,10}$ (Chart 2).

Despite the numerous indications, in general practice, bronchial challenges are mostly used for confirming the diagnoses of asthma, EIB and cough-variant asthma, and for assessing elitelevel athletes, as will be discussed subsequently., ${ }^{40}$

\section{The use of bronchial provocation tests in diagnosing asthma}

A correct diagnosis for asthma is essential for adequate therapy. Asthma generally manifests with symptoms of episodic breathlessness, wheezing, coughing and chest tightness and is confirmed through airflow limitation and reversibility, as detected through lung function tests (spirometry or peak expiratory flow). ${ }^{18}$ Other tests, such as measurements of allergic status, airway responsiveness and inflammation, can be used in atypical presentations. ${ }^{18}$

Among patients with symptoms consistent with asthma who present normal lung function, an objective measurement such as a bronchial challenge, with direct or indirect stimuli, may help establish a diagnosis of asthma. ${ }^{10,19,20}$ In these patients, detection of BHR suggests the diagnosis of asthma. The level of BHR in the bronchial challenge can also be used. Although there is no threshold that differentiates asthma from other diseases that present BHR, the BHR of asthma patients is usually more severe. Therefore, there is a correlation between the degree of airway responsiveness and asthma symptoms, ${ }^{21,22}$ e.g. a histamine or methacholine $\mathrm{PC}_{20}$ greater than 8 (or 16 ) $\mathrm{mg} / \mathrm{ml}$ rules out current asthma in most instances, whereas a $\mathrm{PC}_{20}$ less than $1 \mathrm{mg} / \mathrm{ml}$ is almost diagnostic of current asthma. Values between 1 and $8 \mathrm{mg} / \mathrm{ml}$ are intermediate in this regard. ${ }^{23}$ Since bronchial challenges have high sensitivity and limited specificity, a negative result can be useful for ruling out a diagnosis of persistent asthma, but a positive result does not always confirm the diagnosis. ${ }^{18,21,23}$ If the diagnosis after the bronchial challenge results remains uncertain,

\section{Chart 2. Indications for a bronchial challenge}

\section{To confirm the diagnosis of asthma}

To confirm the diagnosis of exercise-induced bronchoconstriction

To investigate cough-variant asthma

To identify and evaluate the response and efficacy of drugs, like antiinflammatory drugs

To collect sputum

To identify those who may experience airway narrowing while diving with self-contained underwater breathing apparatus (SCUBA)

To clear unwanted secretions

To differentiate asthma from chronic airflow limitation

To evaluate elite-level athletes other tests, such as prick test, IgE measurement or induced sputum can be used as measurements of allergic status and airway inflammation, and/or a therapeutic test could be initiated.

It is important to evaluate the patient's clinical status and the medications used, given that the BHR is a dynamic process that can vary over time. It can increase after exposure to various environmental sensitizers and drugs (e.g. airborne allergens, substances found at the workplace, respiratory infections or propranolol), and it can decrease spontaneously or after anti-inflammatory therapy. ${ }^{21,24,25}$

\section{The use of bronchial provocation tests in diagnosing cough-variant asthma}

Asthma is one of the most common etiologies among patients with a chronic cough. Other common diagnoses are postnasal drip syndrome and gastroesophageal reflux. ${ }^{26,27}$ Some patients with asthma have coughing as the sole symptom, and this is termed coughvariant asthma. ${ }^{28}$ Therefore, among patients with a chronic cough, asthma should always be considered as a potential etiology. ${ }^{26}$

Among patients with a chronic cough associated with reversible airway flow obstruction, the diagnosis of asthma should be considered and treatment for asthma should be initiated. However, among patients with a chronic cough and normal spirometry, additional tests should be done, including bronchial challenge. In these patients, the presence of BHR documented in a bronchial challenge suggests the diagnosis of asthma, and treatment should be initiated in order to confirm the diagnosis. Evaluation of treatment response is essential, since the diagnosis of asthma is confirmed only when a positive bronchial challenge is followed by a favorable response to asthma therapy, usually with the use of inhaled corticosteroids for one week. ${ }^{29}$ On the other hand, given the high specificity of bronchial challenges, a negative result rules out asthma from the differential diagnosis of chronic cough. ${ }^{1}$ Methacholine has been the stimulus most frequently indicated and used in cough-variant asthma investigations. Some studies have demonstrated that indirect stimuli could also be used, but more studies are needed before that can be used in routine practice..$^{30,31}$

\section{Bronchial provocation tests in exercise-induced bronchoconstriction}

Exercise-induced bronchoconstriction (EIB) is characterized by an acute, transient airway narrowing that occurs during and most often after exercise. ${ }^{32}$ Common symptoms include coughing, wheezing, chest tightness and dyspnea, usually 5 to $10 \mathrm{~min}$ after exercise ceases, and they can remain significant for $30 \mathrm{~min}$ if no therapy is provided.$^{33} \mathrm{EIB}$ is more frequent after vigorous exercise and in cold and dry weather. EIB is found in 50 to $90 \%$ of all asthmatic patients and also occurs in up to $10 \%$ of subjects who are not known to be atopic or asthmatic. ${ }^{34,35}$ The prevalence of EIB 
among athletes is higher, and notifications by athletes have been increasing in recent Olympic Games. ${ }^{32,36}$ Because athletes without asthma may have been using inhaled $\beta 2$-agonists in order to improve performance, it has been recommended that athletes should demonstrate current asthma, EIB or BHR in order to be approved to inhale $\beta 2$-agonists at the Olympic Games. ${ }^{36}$

Among patients with a diagnosis of asthma, a complete history associated with therapeutic test is enough for a diagnosis of EIB. Among patients with symptoms of EIB and normal spirometry, and among elite athletes, bronchial challenges are necessary. The most accurate tests for assessing EIB are exercise, eucapnic voluntary hyperpnea, hyperosmolar aerosols such as $4.5 \%$ saline, mannitol and methacholine. ${ }^{32,36}$ Because the airway response depends on the intensity of exertion and on environmental variables such as temperature, air humidity and time of the day, ${ }^{37,38}$ it is crucial to know the conditions under which the bronchial challenge was done, in order to make an appropriate interpretation of its results. ${ }^{39}$

For elite athletes, the bronchial challenges accepted are exercise, eucapnic voluntary hyperpnea, hyperosmolar aerosols such as $4.5 \%$ saline, mannitol and methacholine. For exercise and eucapnic voluntary hyperpnea, a fall in $\mathrm{FEV}_{1}$ of $10 \%$ is consistent with EIB; for hypertonic saline and mannitol, a fall in $\mathrm{FEV}_{1}$ of $15 \%$ is considered to be BHR; and, for methacholine, a fall in $\mathrm{FEV}_{1}$ of $20 \%$ confirms EIB diagnosis. Bronchial challenges with other stimuli, such as carbachol, histamine or adenosine monophosphate, have not been accepted by the International Olympic Committee's Medical Commission. ${ }^{36}$ Although laboratory-based challenges can be used for identifying EIB, field-based bronchial challenge has been found to be more sensitive. ${ }^{40}$ Moreover, the sensitivity of methacholine for identifying EIB in elite athletes has been reported to be low and less than $40 \%$. Therefore, among elite athletes, a negative methacholine challenge does not completely rule out EIB, and an indirect stimulus can be used for further evaluation. ${ }^{36,41,42}$ Since many other conditions can mimic EIB, a detailed clinical history and physical examination should precede the bronchial challenge.

\section{Perspectives}

Bronchial challenges are useful in studying pathophysiological characteristics of respiratory diseases, such as the relationship between bronchial responsiveness and airway inflammation and remodeling. They could also be used as an index for asthma severity and clinical control. Moreover, bronchial challenges are an essential step in the development of new anti-asthma treatments and can provide key information on the therapeutic potential of these new agents and their anti-inflammatory effects on the airways. ${ }^{43-45}$

Because of the lack of a reference diagnostic test (gold standard), it is difficult to determine the exact sensitivity and specificity of each different stimulus and for each disease. Some studies rely on physician diagnosis as the gold standard, but such assessments are highly subjective. ${ }^{41}$

Several studies have aimed to use bronchial challenge as an additional therapeutic choice. In cystic fibrosis, inhaled mannitol treatment significantly improved lung function. ${ }^{46}$ We have demonstrated that performing two hypertonic saline challenges in the evening attenuated the nocturnal fall in $\mathrm{FEV}_{1}$ among asthmatic patients. ${ }^{47}$

Epidemiological studies on asthma have been hampered by lack of consistency in the results between reports. Most definitions of asthma have emphasized variable airflow obstruction and highlighted inflammation as essential elements of the condition. However, a positive BHR has been used as a relative standard criterion of validity. The association between positive BHR and symptoms has been seen as a gold standard definition of asthma and is a matter discussed in recent studies on asthma detection in large populations. ${ }^{48,49}$

\section{REFERENCES}

1. Crapo RO, Casaburi R, Coates AL, et al. Guidelines for methacholine and exercise challenge testing-1999. This official statement of the American Thoracic Society was adopted by the ATS Board of Directors, July 1999. Am J Respir Crit Care Med. 2000;161(1):309-29.

2. Joos GF. Bronchial hyperresponsiveness: too complex to be useful? Curr Opin Pharmacol. 2003;3(3):233-8.

3. Sterk PJ, Fabbri LM, Quanjer PH, et al. Airway responsiveness. Standardized challenge testing with pharmacological, physical and sensitizing stimuli in adults. Report Working Party Standardization of Lung Function Tests, European Community for Steel and Coal. Official Statement of the European Respiratory Society. Eur Respir J Suppl. 1993; 16:53-83.

4. Joos GF, O'Connor B, Anderson SD, et al. Indirect airway challenges. Eur Respir J. 2003;21(6):1050-68.

5. Van Schoor J, Joos GF, Pauwels RA. Indirect bronchial hyperresponsiveness in asthma: mechanisms, pharmacology and implications for clinical research. Eur Respir J. 2000;16(3):514-33.

6. Boulet LP, Laviolette M, Turcotte $H$, et al. Bronchial subepithelial fibrosis correlates with airway responsiveness to methacholine. Chest. 1997;112(1):45-52

7. Cockcroft DW, Davis BE. Mechanisms of airway hyperresponsiveness, J Allergy Clin Immunol. 2006;118(3):551-9; quiz 560-1.

8. Martin JG, Duguet A, Eidelman DH. The contribution of airway smooth muscle to airway narrowing and airway hyperresponsiveness in disease. Eur Respir J. 2000;16(2): 349-54.

9. Beydon N, Davis SD, Lombardi E, et al. An official American Thoracic Society/European Respiratory Society statement: pulmonary function testing in preschool children. Am J Respir Crit Care Med. 2007;175(12):1304-45. 
10. Anderson SD, Brannan JD. Methods for «indirect» challenge tests including exercise, eucapnic voluntary hyperpnea, and hypertonic aerosols. Clin Rev Allergy Immunol. 2003;24(1):27-54.

11. de Meer G, Marks GB, Postma DS. Direct or indirect stimuli for bronchial challenge testing: what is the relevance for asthma epidemiology? Clin Exp Allergy. 2004;34(1):9-16.

12. Joos GF, Kips JC, Pauwels RA. Direct and indirect bronchial responsiveness. Respir Med. 1993;87 Suppl B:31-6.

13. Brannan JD, Gulliksson M, Anderson SD, Chew N, Kumlin M. Evidence of mast cell activation and leukotriene release after mannitol inhalation. Eur Respir J. 2003;22(3):491-6.

14. O'Sullivan S, Roquet A, Dahlén $B$, et al. Evidence for mast cell activation during exercise-induced bronchoconstriction. Eur Respir J. 1998;12(2):345-50.

15. Worldwide variation in prevalence of symptoms of asthma, allergic rhinoconjunctivitis, and atopic eczema: ISAAC. The International Study of Asthma and Allergies in Childhood (ISAAC) Steering Committee. Lancet. 1998;351(9111):1225-32.

16. Rodwell LT, Anderson SD, Seale JP. Inhaled steroids modify bronchial responses to hyperosmolar saline. Eur Respir J. 1992;5(8):953-62.

17. Pauwels R, Joos G, Van der Straeten M. Bronchial hyperresponsiveness is not bronchial hyperresponsiveness is not bronchial asthma. Clin Allergy. 1988;18(4):317-21.

18. Global Strategy for Asthma Management and Prevention. South Africa: University of Cape Town Lung Institute; 2008. Available from: http://www.medicinainterna.org.uy/Articulos/Neumologia/GINA_ Report_08.pdf. Accessed in 2011 (Jan 28).

19. Adelroth E, Hargreave FE, Ramsdale EH. Do physicians need objective measurements to diagnose asthma? Am Rev Respir Dis. 1986;134(4):704-7.

20. Cockcroft DW. Bronchoprovocation methods: direct challenges. Clin Rev Allergy Immunol. 2003;24(1):19-26.

21. Boulet LP. Asymptomatic airway hyperresponsiveness: a curiosity or an opportunity to prevent asthma? Am J Respir Crit Care Med. 2003;167(3):371-8.

22. Cockcroft DW, Killian DN, Mellon JJ, Hargreave FE. Bronchial reactivity to inhaled histamine: a method and clinical survey. Clin Allergy. 1977;7(3):235-43.

23. Cockcroft DW, Murdock KY, Berscheid BA, Gore BP. Sensitivity and specificity of histamine $\mathrm{PC} 20$ determination in a random selection of young college students. J Allergy Clin Immunol. 1992;89(1 Pt 1):23-30.

24. Rijcken B, Schouten JP, Weiss ST, et al. Long-term variability of bronchial responsiveness to histamine in a random population sample of adults. Am Rev Respir Dis. 1993;148(4 Pt 1):944-9.

25. Carpentiere G, Castello F, Marino S. Increased responsiveness to histamine after propranolol in subjects with asthma nonresponsive to the bronchoconstrictive effect of propranolol. J Allergy Clin Immunol. 1988;82(4):595-8.

26. Dicpinigaitis PV. Chronic cough due to asthma: ACCP evidencebased clinical practice guidelines. Chest. 2006;129(1 Suppl):75S-9S.
27. Irwin RS, Curley FJ, French CL. Chronic cough. The spectrum and frequency of causes, key components of the diagnostic evaluation, and outcome of specific therapy. Am Rev Respir Dis. 1990;141 (3):640-7.

28. Corrao WM, Braman SS, Irwin RS. Chronic cough as the sole presenting manifestation of bronchial asthma. N Engl J Med. 1979;300(12):633-7.

29. Irwin RS, French CT, Smyrnios NA, Curley FJ. Interpretation of positive results of a methacholine inhalation challenge and 1 week of inhaled bronchodilator use in diagnosing and treating cough-variant asthma. Arch Intern Med. 1997;157(17):1981-7.

30. Ribeiro M, Pereira CA, Nery LE, Beppu OS, Silva CO. Methacholine vs adenosine on intra and extrathoracic airway hyperresponsiveness in patients with cough variant asthma. Allergy. 2008;63(5):527-32.

31. Singapuri A, McKenna S, Brightling CE. The utility of the mannitol challenge in the assessment of chronic cough: a pilot study. Cough. 2008;4:10

32. Parsons JP, Mastronarde JG. Exercise-induced bronchoconstriction in athletes. Chest. 2005;128(6):3966-74.

33. Brudno DS, Wagner JM, Rupp NT. Length of postexercise assessment in the determination of exercise-induced bronchospasm. Ann Allergy. 1994;73(3):227-31.

34. Gotshall RW. Exercise-induced bronchoconstriction. Drugs. 2002;62(12):1725-39.

35. Rundell KW, Jenkinson DM. Exercise-induced bronchospasm in the elite athlete. Sports Med. 2002;32(9):583-600.

36. Fitch KD, Sue-Chu M, Anderson SD, et al. Asthma and the elite athlete: summary of the International Olympic Committee's consensus conference, Lausanne, Switzerland, January 22-24, 2008. J Allergy Clin Immunol. 2008;122(2):254-60, 260.e1-7.

37. Ferraz E, Borges MC, Terra-Filho J, Martinez JA, Vianna EO. Comparison of $4 \mathrm{AM}$ and $4 \mathrm{PM}$ bronchial responsiveness to hypertonic saline in asthma. Lung. 2006;184(6):341-6.

38. Vianna EO, Boaventura LC, Terra-Filho J, et al. Morning-to-evening variation in exercise-induced bronchospasm. J Allergy Clin Immunol. 2002;110(2):236-40.

39. McFadden ER Jr, Gilbert IA. Exercise-induced asthma. N Engl J Med. 1994;330(19):1362-7.

40. Rundell KW, Wilber RL, Szmedra L, et al. Exercise-induced asthma screening of elite athletes: field versus laboratory exercise challenge. Med Sci Sports Exerc. 2000;32(2):309-16.

41. Cockcroft DW, Davis BE. Diagnostic and therapeutic value of airway challenges in asthma. Curr Allergy Asthma Rep. 2009;9(3):247-53.

42. Holzer K, Anderson SD, Douglass J. Exercise in elite summer athletes: Challenges for diagnosis. J Allergy Clin Immunol. 2002;110(3):374-80.

43. BouletLP,GauvreauG,BoulayME,etal.Theallergenbronchoprovocation model: an important tool for the investigation of new asthma antiinflammatory therapies. Allergy. 2007;62(10):1101-10.

44. Pogson ZE, Antoniak MD, Pacey SJ, et al. Does a low sodium diet improve asthma control? A randomized controlled trial. Am J Respir Crit Care Med. 2008;178(2):132-8. 
45. Wenzel S, Wilbraham D, Fuller R, Getz EB, Longphre M. Effect of an interleukin-4 variant on late phase asthmatic response to allergen challenge in asthmatic patients: results of two phase 2a studies. Lancet. 2007;370(9596):1422-31.

46. Jaques A, Daviskas E, Turton JA, et al. Inhaled mannitol improves lung function in cystic fibrosis. Chest. 2008;133(6):1388-96.

47. Borges MC, Ferraz E, Terra-Filho J, Vianna EO. Protective effect of bronchial challenge with hypertonic saline on nocturnal asthma. Braz J Med Biol Res. 2008;41 (3):209-14.

48. Caldeira RD, Bettiol H, Barbieri MA, et al. Prevalence and risk factors for work related asthma in young adults. Occup Environ Med. 2006;63(10):694-9.

49. Vianna EO, Garcia CA, Bettiol H, Barbieri MA, Rona RJ. Asthma definitions, relative validity and impact on known risk factors in young Brazilians. Allergy. 2007;62(10):1146-51.

\section{Conflict of interest: None}

Sources of funding: Not declared

Date of first submission: February 26, 2009

Last received: September 13, 2010

Accepted: February 24, 2011

\section{Address for correspondence:}

Elcio Oliveira Vianna

Divisão Pulmonar — Departamento de Medicina

Universidade de São Paulo, Faculdade de Medicina de Ribeirão Preto

Av. Bandeirantes, 3.900

Ribeirão Preto (SP) — Brasil

CEP 14048-900

Tel. (+55 16) 3602-2706

Fax. (+55 16) 3633-6695

E-mail:evianna@uol.com.br 